\title{
THE EFFECT OF ACCOUNTING PLANT ASSETS AND LEADING COMMITMENT TO GOOD CORPORATE GOVERNANCE AND EFFECT PERFORMANCE FINANCE IN PERUM PERHUTANI HOLDING : DRAFT A PROPOSAL
}

\author{
Retno Martanti Endah Lestari*), Ida Farida \\ Pakuan University \\ retno.martanti@unpak.ac.id
}

\begin{abstract}
This paper discuss about PSAK 69 agriculture with specific focus on accounting of plant assets can effect performance finance in Perhutani holding, Indonesia. Biological asset are plants and animals undergoing biological transformations. Biological transformation consists of the process of growing, developing, producing and ready quotes that lead to changes both qualitatively and quantitatively. This raises the needs of various parties regarding the ability of the aplication of PSAK 69 in biological asset, especially on the use of present value of the model of cash inflows in the future to determine the fair value of biological asset certain categories. The results of the proposed study would hopefully assist in the development of an alternative fair value model in valuing plant assets supported by leading commitment and subsequently lead to good corporate governance specifically on the performance finance.
\end{abstract}

Keywords: Accounting of Plant Assets, Performance Finance.

\begin{abstract}
Abstrak
Makalah ini membahas tentang PSAK 69 pertanian dengan fokus khusus pada akuntansi aset tanaman dapat mempengaruhi kinerja keuangan di Perhutani holding, Indonesia. Aset biologis adalah tumbuhan dan hewan yang mengalami transformasi biologis. Transformasi biologis terdiri dari proses tumbuh, berkembang, memproduksi dan siap petik yang mengarah pada perubahan baik secara kualitatif dan kuantitatif. Hal ini menimbulkan kebutuhan berbagai pihak berkenaan dengan kemampuan penerapan PSAK 69 dalam aset biologis, terutama pada penggunaan nilai sekarang dari model arus kas masuk di masa depan untuk menentukan nilai wajar aset biologis kategori tertentu. Hasil studi yang diusulkan diharapkan akan membantu dalam pengembangan model nilai wajar alternatif dalam menilai aset tanaman yang didukung oleh komitmen utama dan kemudian mengarah pada tata kelola perusahaan yang baik khususnya pada kinerja keuangan.
\end{abstract}

Kata Kunci: Akuntansi Aset Tanaman, Kinerja Keuangan. 


\section{INTRODUCTION}

The accounting provisions that become the guideline for the preparation of the financial statements continue to change in line with the developments and changes in transactions and business activities, as well as changes in accounting concepts that seek to reflect the economic substance of transactions and business activities in the financial statements. This change is done so that the purpose of financial statements can still be achieved that is by the fulfillment of aspects of relevance, reliability, ease of understanding and comparison.

Changes in accounting provisions for forestry companies began to undergo major changes since January 1, 2010 with the effective revocation of PSAK 32: Accounting for Forestry. Currently the Ministry of Environment and Forestry has provided guidance for forestry companies. There are several regulations governing the financial statements of forestry companies.

This regulation provides technical translation of the general requirements of IFRSs that are relevant to forestry companies. The regulation is Minister of Forestry Regulation Number P.69 / Menhut-II / 2009 concerning Guidelines on Financial Reporting of Forest Production Utilization and Forest Management (Dolapkeu-PHP2H) effective on January 1, 2010. Subsequently issued Forestry Minister Regulation Number P.32 / Menhut -II / 2014 on the Financial Reporting Guidelines for the Utilization of Production Forest and Forest Management (Dolapkeu-PHP2H) effective on 3 June 2014.

With these guidelines, the company has guidance referred to in preparing financial statements. A valuable lesson from PSAK 32 is to make standards not allowed by reference to industry-specific regulations issued by the government.

Standards should be developed with the concept of accounting concepts and basic principles and supported by theory. Changes in accounting principles must be done carefully and given sufficient disclosure, so as not to cause readers difficulties in understanding the financial statements, explained by Dwi Martani (2010).

The main issue for Perum Perhutani and other private companies in the preparation of the current financial statements is the accounting treatment of crop costs in production forest areas. In SFAS: Forestry Accounting that is no longer applicable at present, all costs of crops in production forest are recognized as an expense. In the Regulation of the Minister of Forestry Number P.69 / Menhut-II / 2009 amended by Regulation of the Minister of Forestry Number P.32 / MenhutII / 2014 regulates the cost of crops in production forests recognized as assets. While in the Minister of Forestry Regulation No. P.23 / Menhut-II / 2012 specifically Perum Perhutani, the cost of crops in production forests is recognized as an expense.

The difference in the above regulation provisions raises the question of how accounting requirements should be related to the costs of crops in Perum Perhutani's production forest areas and other private forestry enterprises. This issue is urgent to be resolved as it will become the foundation for forestry companies in implementing the adoption of IAS 41 Agriculture. If the plant in a production forest area is not an asset, then the adoption of IAS 41 becomes 
irrelevant because there is no biological asset in the financial statements of the forestry company.

However, if the plant is a biological asset, either bearier plant or consumable plant in the financial statements, as explained by Dwi Martani / IAI on accounting studies on the cost of plants in the area for production. Indonesia began to adopt IAS 41 on January 1, 2018 which is the effective enactment of PSAK 69 agriculture.

Leadership Commitment is also a variable that affects the financial performance of a company. As a result of Nektarios's (2015) study, that top management commitment positively affects top management involvement. In addition, the ultimate involvement of top management mediates the relationship between top management commitment and relationship quality. Finally, the quality of positive relationships is related to financial performance.

Thus the author assumes that the two variables have a relationship that was going on explained in the study results. By using these two macroeconomic variables, expressed in actual value, expect to be able to see how the second relationship and result in this variable in the short-term and long-term, as well as on the expected can see if there is a dependency between macroeconomic variables in doing this research. This research will be divided into 5 sections, where section 1 is for introduction, part 2 for literature review, part 3 for research methods, part 4 for results research and part 5 for conclusion research that has been funded.

How big is the effect of accounting policy on plant assets, production cost determination, leadership commitment and Good Corporate Governance practices on financial performance?

\section{LITERATURE REVIEW}

For literature pertaining for this study, the authors use as the basis of the literature as a basis for understanding the use of modeling in research methodsthat will be in use. One of them performed by Muhammad, et, al (2014), Elad \& Herbohn (2011), Athanasios (2010), Levan (2015), Martani (2010). They reasearch related to biological asset to performance finance.

The other variables affecting the good corporate governance practices of the forestry sector in this research are leadership commitments, where the Leadership Commitment is the direct leadership involvement to provide resources, establish policies, and communicate well with stakeholders in terms of following up on the findings to produce financial reporting quality. (Adha, et.al, 2014; Noviandini et.al, 2015; Tzempelikos, 2015; Njie, et.al, 2008; Mackness, 1991; Colwell \& Joshi; 2011; Powell \& Colyvas; 2008; Oruma, 2014; Zakuan et al., 2012).

Other variables that can affect the financial performance of good corporate governance practices, which Based on the Decree of the Minister of State-Owned Enterprises KEP-117 / M-MBU / 2002, Good Corporate Governance is a process of the structure used by SOE organs to improve business success and accountability is a process of the structure used by SOE organs to improve 
business success and corporate accountability in order to realize shareholder value in the long term while keeping the interest of other stakeholders based on the rules of law and ethics.

Earlier researchers concluded that Good Corporate Governance Practices affects financial performance, Nurcahyani, 2013; Diah, 2012; Supatmi, 2007; Dani, 2011; Ahmad \& Mansur, 2012; Benjamin Fung, 2014; Stephen Oswald Maluka, 2011; Zahroh \& Hamidah, 2017; Emel, Oya and Erkut, 2017; Fatma, Ugur, Erkan and Tamer, 2015; Philip, et al, 2014).

\subsection{Influence of Plant Asset Accounting Policies, Leadership Commitment and Good Corporate Governance Practices on Financial Performance}

The results of Ullah, et al (2017) show that corporate governance has a positive effect on financial performance. This study not only contributes to understanding the influence and relationship between corporate governance and financial performance but at the same time proves previous research results that have shown significant effects and the relationship between corporate governance and financial performance.

Alberto (2015) argues that corporate leaders Persistence, passion, and commitment to ethics will enhance their individual reputation along with their organization's reputation. The corporate leader who has neglected professionalism in his or her business activities has caused a corporate financial mistake affecting investors and the overall economy in Nigeria.

Alberto (2015) argues that unethical behavior in the banking sector has caused billions of dollars of losses, legal battles, disadvantaged organizations' reputation, and created financial vulnerabilities.Bankers who show their professionalism the description of their work and responsibilities; affirming organizational goals; and demonstrate integrity, sincerity, and ability.

Isaac (2014) affirms that concerns about corporate governance stem from the certainty that good governance by banks will result in better services, strategic bank management, enterprise value markets, cost reduction funds, and higher profitability. Agency theory explains that effective corporate governance can lead to improved performance and financial results.

In Ishola's research (2017) found a positive but statistically insignificant relationship between corporate governance mechanisms and financial performance. This study has implications for positive social change by showing managers and other stakeholders how a good corporate governance system guarantees investor confidence, employee loyalty and commitment, reduces interest cost conflicts and agencies, and strong financial performance. Hypothesis of this research is that application of plant asset accounting, commitment of leadership and practice of good corporate governance have an effect on to financial performance. 


\section{RESEARCH METHOD}

The method used by researchers is explanatory research. To conduct research, must first be determined which populationwill be examined. As Sugiyono (2014: 119) on population iss follows:"Population is a generalization region consisting of objects or subjects that arehas a certain quantity and character set by the researcherto be studied and then to draw conclusions".

While understanding the population according to Uma Sekaran (2011: 64) asfollowing:"Population is the whole group of people, events, or things you wantinvestigative researcher".

Based on the understanding of the two expert opinions mentioned above then it is concluded that the population is not just people, but also objects and objectsother nature. Population is also not just the number of objects / subjectsstudied, but encompasses all the characteristics / properties possessed by that subjectinvestigated.

The population of this research is the branch offices of Perum Perhutani as much as 70 Forestry Offices spread across the territory of Indonesia. According Sugiyono (2014: 120), understanding samples are as follows:"The sample is part of the number and characteristics possessed bythe population. When the population is large and impossibleresearch on all members of the population then can usesamples taken from the population."

Sample measurement is a step to determine the magnitudesamples taken in conducting a study. Aside from thatit should be noted that the selected sample should show all the characteristicspopulation so that it is reflected in the selected sample, in other words the samplemust be able to describe the actual or representative state of the population(representative).

To calculate the determination of the number of samples from a given populationdeveloped, then used Slovin formula. In determining the number of samples to be selected, the author useserror rate of $5 \%$, because in each study may not be the resultperfect $100 \%$, the greater the error rate the less the sample size.Total population as the basis of calculation used is 70 office, thus, of the population members taken as samples is 60 samples.

Data collection was done through the distribution of questionnaires to the respondents included in the unit of research analysis. Each company is given 3 (three) questionnaires for the director, head chief financial officer / chief accountant and production director / head of accountancy department.

Questionnaires will be distributed by visiting directly to respondents, through contact person, post and via electronic mail. Operationalization of variables in this study is determined based on four variables, namely Accounting for Plant Assets, Leadership Commitment, Good Corporate Governance Practices, and Financial Performance. To further clarify the operationalization of variables and definitions of variables, the substance of variable definition and operationalization of variables are grouped into: variables, dimensions, indicators, and scales.

Because of this research using SEM method, then the calculation of the number of samples also pay attention to the rule of thumb of the SEM method.In 
order to provide a more comprehensive result, the proposed study will also use professional valuers. Professional valuers are chosen as the sample study since they have vast experience in valuation, and selling and disposal of land and most likely would have experiences in valuing land that has bearer biological assets.

The proposed study will select professional valuers located in Perum Perhutani, Indonesia. Apart from interviewing the professional valuers, valuation reports from the professional valuers will also be used in order to gain further understanding on fair valuation of bearer biological assets.Hypothesis testing is done using approach method of Structural Equation Modeling (SEM).

Structural Model :

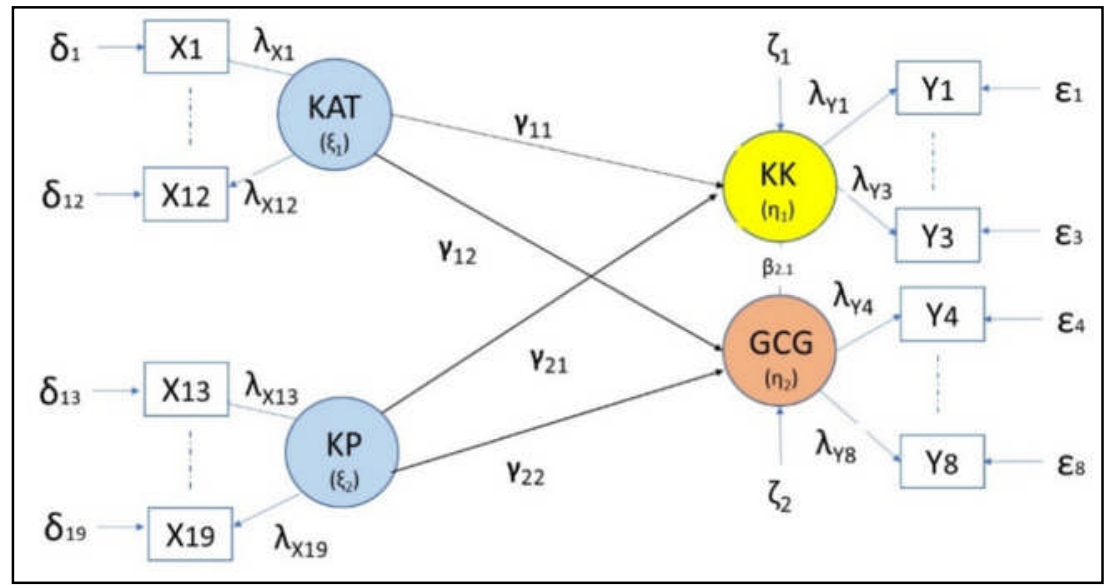

(Lisrel 8.72)

Model equation is :

$\eta_{1}=\gamma_{1.1} \xi_{1}+\gamma_{1.2} \xi_{2}+\zeta_{1}$

$\eta_{2}=\beta_{2.1} \eta_{1}+\gamma_{2.1} \xi_{1}+\gamma_{2.2} \xi_{2}+\zeta_{2}$

Information :

$\eta_{1}=$ variable performance finance

$\eta_{2}=$ variable good corporate governance

$\gamma=$ coefficient of path between exogenous latent variables

$\xi_{1}=$ variable accounting policy of plant asset

$\xi_{2}=$ variable of leadership commitment

$\zeta_{1}=$ error measurement of endogenous latent variables

$\beta=$ path coefficient between endogenous latent variables

\section{RESULTS \& CONCLUSION}

The proposed study will have little contribution. First, the findings of this study will help finance report makers to comply with the requirements of PSAK 
69 agriculture to disclose the fair value of biological assets in the notes to the financial statements that will affect the performance of corporate finance in the forestry.

The second is to give the company strength that the commitment of the leaders of Perum Perhutani is strongly required to run accountancy of psak 69 supported by the implementation of good corporate governance practices which will ultimately assist the company in creating its financial performance.

The third is to contribute meaningfully that when good corporate governance practices are implemented, it will create good financial performance.

In summary, the findings of the proposed study will provide an alternative or improvement to the existing measurement method of bearer biological assets. The fair value model developed could enhance qualitative characteristics of useful financial information related to fair value bearer biological asset.

This in turn would promote good corporate governance practices among the plantation companies in Indonesia. This paper also provides some knowledge on the fair value accounting of bearer biological assets and such understanding would benefits the companies, statement preparers, statement users and the standard setters on the fair valuation of bearer biological assets.

\section{REFERENCES}

Adha, Wendi, Rahmawati, Vince, and Al Azhar. (2014). Pengaruh Akuntabilitas, Ketidakpastian Lingkungan, dan Komitmen Pimpinan Terhadap Penerapa Transparansi Pelaporan Keuangan (Studi Empiris Pada SKPD Kota Dumai). JOM Fekon Vol. 1 No. 2 Oktober 2014.

Ahmad Bawa Abdul-Qadir dan Mansur Lubabah Kwanbo, (2012). Corporate Governance And Financial Performance Of Banks In The PostConsolidation Era In Nigeria. International Journal Of Social Sciences And Humanity Studies Vol 4, No 2, 2012 Issn: 1309-8063 (Online).

Alberto, M., (2015). Professionalism in banking: The best root to recovery. Aestimatio. The International Journal of Finance, 10, 2-13. doi:10.5605/IEB.10.6 Anual Report Perhutani : 2016

Athanasios, V., Stergios, A., Laskaridou, E.C. (2010), The importance of information through accounting practice in agricultural sector - European data network. Journal of Social Sciences, 6: 221-228

Colwell, Scott R. , and Joshi, Ashwin W., .(2011). Corporate Ecological Responsiveness: Antecedent Effects of Institutional Pressure and Top Management Commitment and Their Impact on Organizational Performance. Journal of Business Strategy and the Environment Bus. Strat. Env.

Dani Riandi dan Hasan Sakti Siregar, (2011). Pengaruh Penerapan Good Corporate Governance Terhadap Return On Asset, Net Profit Margin, Dan Earning Per Share Pada Perusahaan Yang Terdaftar Di Corporate Governance Perception Index. Jurnal Ekonom, Vol 14, No 3, Juli 2011. 
Diah Nurriza, Indah Permata, Fariyana Kusumawati, Rindah F. Suryawati, (2012). Pengaruh Penerapan Good Corporate Governance Terhadap Kinerja Keuangan Perusahaan. Jurnal InFestasi, Fakultas Ekonomi, Universitas Trunojoyo Madura, Vol. 8 No.2 Desember 2012, Hal. 171 - 178

Elad, C., \& Herbohn, K. (201)1. Implementing Fair Value Accounting in the Agricultural Sector, The Institute of Chartered Accountants of Scotland, Edinburgh.

Emel Burak, Oya Erdil and Erkut Altindağ, (2017). Effect Of Corporate Governance Principles On Business Performance. Australian Journal of Business and Management Research New South Wales Research Centre Australia (NSWRCA), Vol.05 No.07, ISSN: 1839 - 0846.

Fatma Ayanoglu Sisman ${ }^{1}$, Ugur Yozgat ${ }^{2}$, Erkan Abunaz3, Tamer Ozarslan, (2015). Importance Of Transparency On Sustainable Success Orientation. Research Journal of Business and Management-(RJBM), ISSN: 2148-6689, Volume :2 Issue: 3, DOI: 10.17261/Pressacademia.2015312986.

Fung, Benjamin, (2014). The Demand and Need for Transparency and Disclosure in Corporate Governance. Universal Journal of Management 2(2): 72-80, 2014 http://www.hrpub.org DOI: 10.13189/ujm.2014.020203.

Herbohn, K, J. Herbohn. (2006). International Accounting Standard (IAS) 41: What are The Implications for Reporting Forest Assets?. www.ssrn.com.

Ikatan Akuntan Indonesia, (2017). Standar Akuntansi Keuangan, PSAK 69 Agrikultur.

Isaac, L, (2014). Corporate governance and organizational performance in the Nigerian banking industry. European Journal of Business and Management, 6, 110-118.Retrieved from http://www.iiste.org/Journals/

Kamaruzzaman Muhammad, (2014) A Fair Value Model for Bearer Biological Assets in Promoting Corporate Governance: A Proposal, Macrothink Institute. Journal of Agricultural Studies, ISSN 2166-0379 2014, Vol. 2, No. 1 .

Kerangka Dasar Penyusunan dan Penyajian Laporan Keuangan (KDPPLK)

Martani, Dwi, dkk, Implications of Implementation of IAS 41 about Agriculture on Forestry Accounting in Indonesia.

Martani, Dwi. Slide Agriculture (IAS 41). Maret 4, (2012). http://www.iaiglobal.or.id/prinsip_akuntansi/seminar_ias41/2-Agriculture IAS 41- Dwi Martani.pdf , 2012

Martani, Dwi, et.al. (2010). Dampak Pencabutan PSAK 32 Akuntansi Kehutanan di Indonesia, EBAR.Vol III No. 1, April.

Martani, Dwi, (2010). Penerapan Standar Akuntansi Agrikultur (IAS 41), EBAR, Vol III no. 2 Oktober.

Martani, Dwi. (2014). IAI, Kajian Akuntansi Atas Biaya Tanaman Di Kawasan Untuk Produksi.

Maruli, S dan A.F. Mita. (2010). "Analisis Pendekatan Nilai Wajar dan Nilai Historis dalam Penilaian Aset Biologis pada Perusahaan Agrikultur: Tinjauan Kritis Rencana Adopsi IAS 41." Simposium Nasional Akuntansi XIII Purwokerto. www.sna13purwokerto.com. 
Nektarios Tzempelikos (2015), Top management commitment and involvement and their link to key account management effectiveness, Journal of Business \& Industrial Marketing, 30/1 (2015) 32-44 Emerald Group Publishing Limited [ISSN 0885-8624] [DOI 10.1108/JBIM-12-2012-0238.

Peraturan Menteri Kehutanan Nomor : P.32/Menhut-II/2014 tentang Pedoman Pelaporan Keuangan Pemanfaatan Hutan Produksi (DOLAPKEU-PHP).

Powell WW, Colyvas JA. (2008). Microfoundations of institutional theory. In The Sage Handbook of Organizational Institutionalism, Greenwood R, Oliver C, Sahlin K, Suddaby R (eds). Sage: Thousand Oaks, CA, 276- 298.

Rohani, Jafri Mohd., Yusof, Sha'ri Mohd., Mohamad, Ismail.(2010). The development of a survey instrument for measuring a relationship between statistical process control success factors and performance. Jurnal Mekanikal June 2010, No. 30, pp.1 - 16.

Saur Maruli dan Aria Farahmita, June (2011). The Analysis Of Application Of Fair Value And Historical Cost Approaches In The Valuation Of Biological Assets In The Agricultural Companies. Asia Pacific Journal of Accounting and Finance Volume 1 (2).

Supatmi, (2007). Corporate Governance Dan Kinerja Keuangan. Jurnal Bisnis dan Ekonomi, Vol. 14.

Stephen Oswald Maluka, (2011). Strengthening fairness, transparency and accountability in health care priority setting at district level in Tanzania, Global Health Action. \#2011 Stephen O. Maluka This is an Open Access article distributed under the terms of the Creative Commons AttributionNoncommercial $\quad 3.0 \quad$ Unported License https://creativecommons.org/licenses/by-nc/3.0/), permitting all noncommercial use, distribution, and reproduction in any medium, provided the original work is properly cited. Citation: Global Health Action 2011, 4: 7829 - DOI: 10.3402/gha.v4i0.7829.

Ishola, Toyin Lasisi, (2017). The Relationship between Corporate Governance and Organizational Performance in Nigerian Companies, dissertation, Walden Dissertations and Doctoral Studies Collection.

Tzempelikos,Nektarios. (2015). Top management commitment and involvement and their link to key account management effectiveness. Journal of Business \& Industrial Marketing, Vol. 30 Iss 1 pp. 32 - 44.

Zahroh Naimah dan Hamidah, (2017). The Role of Corporate Governance in Firm Performance, SHS Web of Conferences 3413003 Four A, DOI: $0.1051 /$ shsconf/20173413003.

Zakuan N., Muniandy S., Saman N. Z. \& MdArif M. S. (2012). Critical Success Factors of Total Quality Management Implementation In Higher Education Institution: A Review. International Journal of Academic Research in Business and Social Sciences 2(12), pp.692-699. 